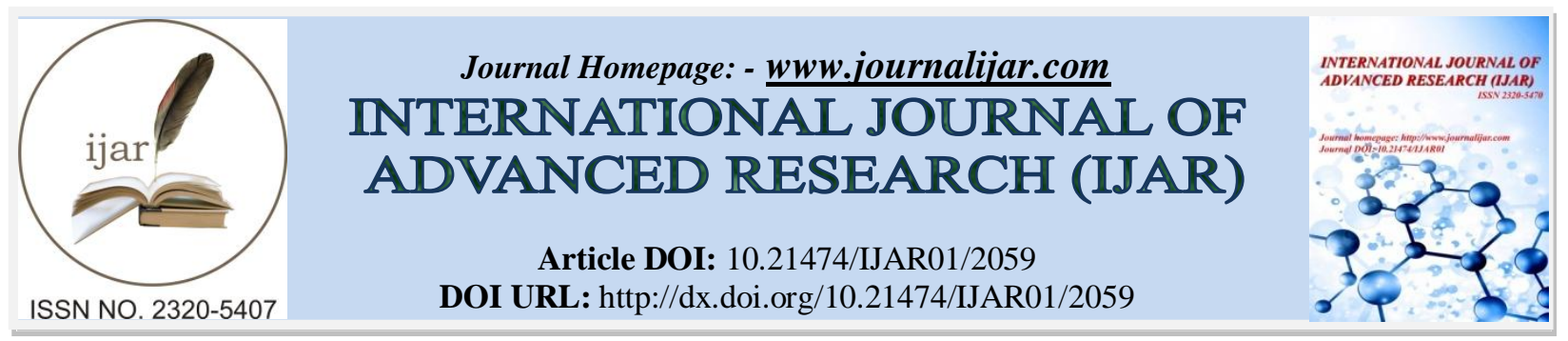

RESEARCH ARTICLE

\title{
ANALYSIS OF THE MULTIPLE INTELLIGENCE FIELDSOF THE SCHOOL OF PHYSICAL EDUCATION AND SPORTS STUDENTS (SAMPLE OF ÇUKUROVA UNIVERSITY SCHOOL OF PHYSICAL EDUCATION AND SPORTS.
}

1. Dumlupinar University.

\author{
Gamze UNALDI ${ }^{1}$ and Mustafa Can KOC ${ }^{2}$.
}

2. Istanbul Gelisim Universty Vocational School

\section{Manuscript Info \\ Manuscript History \\ Received: 23 September 2016 \\ Final Accepted: 25 October 2016 \\ Published: November 2016 \\ Key words:- \\ Multiple Intelligences, Physical \\ Education and Sports, Coaching \\ Education, Sports Management.}

\section{Abstract}

The purpose of this study is to determine the multiple intelligence fields of the students studying in the School of Physical Education and Sports and to analyse the determined fields according to some variables is intended. The "Multiple Intelligences Questionnaire', which originally belongs to McClellan and Conti (2008), whose Turkish validity and reliability test was made by Babacan (2012), which has 3 subdimensions and which consists of 27 entries was used.The statistical methods frequency distribution, per cent (\%) values, average (mean), standard deviation methods and in order to propound the differences between the various variables, ANOVA and in independent groups $t$ test were used on the data set obtained after the practice. The "Tukey" analysis was preferred to be used in order to find the group from which the difference originated for ANOVA. The fallacy level was accepted as $\alpha$ ) 0,05.

In conclusion, differences between the multiple intelligence fields which the SPES students were close to and the variables of age, gender and social class were determined.

Copy Right, IJAR, 2016,. All rights reserved.

\section{Introduction:-}

Education is an active process which provides personal and professional stimuli for the individual to continue his development in a healthy way (1). The process's being active is the necessity for the individual to access to knowledge easily, to be able to make analyses, syntheses and evaluations, to have critical thinking skills and to have values such as developing and renewing himself and being productive (2). Within the scope of this process, the purpose is to help the individual to attain and develop the necessary knowledge, skills and attitudes for him to overcome the problems he faces (1). This point of view has made bringing up democratic and creative individuals who can think critically in a versatile way, who learn how to learn and who can solve problems the most important duty of the educational institutions (3).

Although learning does not have the same meaning with the action of thinking, these two concepts are an inseperable whole. Confucius said "Learning without the action of thinking ends with confusion." The purpose of actualizing learning is to provide thinking. Because of individual differences, differences in thinking and thus differences in the fields of intelligence occur (4). The starting point of the theory of multiple intelligences is to 
enable to form the educational environment in a form far from rote learning, rich in terms of practice and variety, approaching the individuals' different interests and talents seperately (5). The reason is the theory of multiple intelligences which argues that the individual has the ability to develop his intelligence and the intelligence must be approached as a whole in itself although it is versatile. The theory of multiple intelligences is like a window which opens to the human mind and it explains the specific functions of the various parts of the brain. In other words, the theory of multiple intelligences tries to explain how the human being reacts to the content in the World (for example, reactions to various facts, events, sounds or objects) and how he interiorises this content and how he interprets this content in his mind. Thus, when regarded from the point of multiple intelligence theory, intelligence is a versatile capacity, potential or faculty. Moreover, intelligence takes shape with the individual's experiences with his ecological and cultural environment as well as his genetical heredity (6). While the individuals whose verballinguistic intelligence is dominant have the characteristic of being able to use the words effectively in writing and speech, individuals whose logical-mathematical intelligence is dominant are superior to others in using numbers effectively and forming cause effect relationship. In addition, individuals whose visual-spatial intelligence is dominant come into prominence in perceiving their environments and transposing what they perceive correctly, individuals whose bodily-kinesthetic intelligence is dominant make difference in using the body language in expressing their thoughts and emotions and exhibiting the skills they specialize. Individuals whose musical-rhytmic and harmonic intelligence is dominant reveal their difference in perceiving musical forms, interpreting and transforming them, people whose interpersonal intelligence is dominant reveal their difference in interpreting and distinguishing the individuals' moods, emotions and thoughts. Individuals whose intrapersonal intelligence is dominant reveal their difference in knowing their capabilities and transforming it into action. Individuals whose naturalistic intelligencce is dominant reveal their difference is having information about natural life enviroments and evaluating it (7).

In consequence of this study, determinating the multiple intelligence fields of the students who are studying in the departments of School of Physical Education and Sports, Coaching Education and Sports Management is intended. Making contributions to the selection of teaching methods suitable for the variable of intelligence modality and enhancing the students' success are also intended.

The purpose of this study is to determine the multiple intelligence fields of the students studying in the School of Physical Education and Sports and analysing the determined fields of intelligence according to some variables.

\section{Method:- \\ Data Collection Tools:-}

"Multiple Intelligence Survey", which belongs to Mc Clellan and Conti (2008) and whose Turkish validity and reliability test was made by Babacan (2012), which has 3 subdimensions and 27 entries was used as the data collection tool in the research. The survey consists of 27 entries which comprises the nine multiple intelligence fields (Verbal-Linguistic Intelligence, Logical-Mathematical Intelligence, Bodily-Kinesthetic Intelligence, VisualSpatial Intelligence, Interpersonal Intelligence, Intrapersonal Intelligence, Naturalistic Intelligence and Existential Intelligence) approached by Gardner. The 27 entries in the survey divide into three parts and nine entries in each part represent a field of intelligence. The students should write 1 point beside the expression they feel closest to themselves and 9 points beside the expression they think that it is farthest to them. It is intended to determine the field of intelligence the students have tendency to in accordance with the score they take from the survey. The field of intelligence the students have the greatest tendency reveals with the determination of the lowest total score they give to the entries representing the fields of inteligence. The alignments of the questions in each field of intelligence is added and the field of intelligence with the lowest score is considered as the most dominant field of intelligence of the answerer. The lowest score taken from the survey is 3 and the highest score taken from the survey is 27 . The 1 st, 10th and the 19th entries representing the fields of intelligence in the survey were formed as bodily-kinesthetic intelligence. The 2nd, 11th and the 20th entries were formed as existential intelligence, the 3rd, 12th and the 21th entries were formed as interpersonal intelligence, the 4th, 13th and the 22nd entries were formed as intrapersonal intelligence. The 5th, 14th and the 23rd entries were formed as logical-mathematical intelligence, the 6th, 15th and the 24th entries were formed as musical-rhytmic and harmonic intelligence and the 7th, 16th and the 25th entries were formed as naturalistic intelligence. The 8th, 17th and the 26th entries were formed as verbal-linguistic intelligence and the 9th, 18th and the 27th entries were formed as visual-spatial intelligence. The internal consistency coefficent (Cronbach's alpha coefficent) of the survey was found as 0,95 . 


\section{Analysis of the Data:-}

In the analyses applied to the data obtained, frequency distribution, per cent (\%) values, average (mean) and standard deviation methods were used and in order to propound the differences between various variables, ANOVA was used and in independent groups $t$ test was used. Using the "Tukey" analysis was preferred in order to find from which group the difference originated from for ANOVA. The lapse level was accepted as $(\alpha) 0,05$.

\section{Findings:-}

Demographic Findings:-

Totally 205 Physical Education Teaching, Coaching Education and Sports Management students, 88 female (42,9 $\%)$ and 117 male (57,1\%) from Çukurova University School of Physical Education and Sports joined the research. $109(53,2 \%)$ of these students are in the department of physical education teaching, 56 of them $(27,3 \%)$ are in the department of coaching education, 40 of them (19,5\%) are in the department of sports management. When they are analysed according to their years, 59 of them $(28,8 \%)$ are freshmen, 71 of them $(34,6 \%)$ are sophomores, 42 of them $(34,6 \%)$ are juniors and 33 of them $(\% 16,1 \%)$ are seniors.

Table 1:- Dispersion of the Fields of Intelligence According to Gender $(\mathrm{n}=205)$

\begin{tabular}{|c|c|c|c|c|}
\hline & Gender & $\mathrm{N}$ & Average & Standard Deviation \\
\hline \multirow{2}{*}{$\begin{array}{l}\text { Bodily-kinesthetic } \\
\text { intelligence }\end{array}$} & Male & 117 & 7,98 & 4,46 \\
\hline & Female & 88 & 7,08 & 4,14 \\
\hline \multirow{2}{*}{$\begin{array}{l}\text { Existential } \\
\text { Intelligence }\end{array}$} & Male & 117 & 6,29 & 3,56 \\
\hline & Female & 88 & 5,72 & 3,61 \\
\hline \multirow{2}{*}{$\begin{array}{l}\text { Interpersonal } \\
\text { Intelligence }\end{array}$} & Male & 117 & 6,98 & 3,20 \\
\hline & Female & 88 & 5,97 & 3,12 \\
\hline \multirow{2}{*}{$\begin{array}{l}\text { Intrapersonal } \\
\text { Intelligence }\end{array}$} & Male & 117 & 7,04 & 4,16 \\
\hline & Female & 88 & 6,23 & 4,08 \\
\hline \multirow{2}{*}{$\begin{array}{l}\text { Logical-mathematical } \\
\text { Intelligence }\end{array}$} & Male & 117 & 7,64 & 4,30 \\
\hline & Female & 88 & 6,52 & 3,89 \\
\hline \multirow{2}{*}{$\begin{array}{l}\text { Musical-rhythmic } \\
\text { and harmonic } \\
\text { Intelligence }\end{array}$} & Male & 117 & 7,58 & 4,17 \\
\hline & Female & 88 & 6,56 & 3,87 \\
\hline \multirow{2}{*}{$\begin{array}{l}\text { Naturalistic } \\
\text { Intelligence }\end{array}$} & Male & 117 & 7,34 & 3,66 \\
\hline & Female & 88 & 6,23 & 3,46 \\
\hline \multirow{2}{*}{$\begin{array}{l}\text { Verbal-linguistic } \\
\text { Intelligence }\end{array}$} & Male & 117 & 9,26 & 5,64 \\
\hline & Female & 88 & 7,74 & 4,93 \\
\hline \multirow{2}{*}{$\begin{array}{l}\text { Visual-spatial } \\
\text { Intelligence }\end{array}$} & Male & 117 & 7,09 & 3,45 \\
\hline & Female & 88 & 6,25 & 3,41 \\
\hline
\end{tabular}

When the table is analysed, it is seen that women are closer to all of the fields of intelligence when compared to men. While the closest field of intelligence is "existential intelligence" for both sexes, the most distant field of intelligence is determined as "verbal-linguistic intelligence". In this regard, while the 2nd closest field of intelligence for men is interpersonal intelligence, the 2nd closest field of intelligence for women is interpersonal intelligence and intrapersonal intelligence following it.

Table 2:- Dispersion of Fields of Intelligence According to the Variable of Age

\begin{tabular}{|l|l|c|c|c|c|c|c|c|c|c|}
\hline Your age & $\mathbf{B Z}$ & $\mathbf{~ V Z}$ & $\mathbf{K Z}$ & $\mathbf{I Z}$ & $\mathbf{M Z}$ & $\mathbf{M U ̈ Z}$ & $\mathbf{D Z}$ & $\mathbf{S Z}$ & $\mathbf{G Z}$ \\
\hline $\begin{array}{l}18-22 \\
(\mathrm{n}=92)\end{array}$ & $\begin{array}{l}\text { Average Standard } \\
\text { Deviation }\end{array}$ & 8,66 & 7,46 & 7,73 & 8,12 & 7,96 & 7,70 & 7,95 & 9,41 & 8,03 \\
\cline { 2 - 11 } & & 4,01 & 3,60 & 3,07 & 4,00 & 3,88 & 3,67 & 3,41 & 4,54 & 3,41 \\
\hline $\begin{array}{l}23-27 \\
(\mathrm{n}=55)\end{array}$ & $\begin{array}{l}\text { Average Standard } \\
\text { Deviation }\end{array}$ & 7,16 & 5,93 & 6,33 & 7,22 & 6,84 & 7,25 & 6,93 & 8,20 & 6,25 \\
\cline { 2 - 11 } & & 4,25 & 3,30 & 3,14 & 4,39 & 4,07 & 4,19 & 3,86 & 5,26 & 3,27 \\
\hline $\begin{array}{l}28 \text { and } \\
\text { over } \\
(\mathrm{n}=58)\end{array}$ & $\begin{array}{l}\text { Average Standard } \\
\text { Deviation }\end{array}$ & 6,31 & 3,91 & 4,88 & 3,93 & 6,21 & 6,16 & 5,09 & 7,71 & 5,10 \\
\cline { 2 - 11 } $\begin{array}{l}\text { Total } \\
(\mathrm{n}=205)\end{array}$ & $\begin{array}{l}\text { Average Standard } \\
\text { Deviation }\end{array}$ & 4,57 & 2,67 & 2,66 & 2,47 & 4,47 & 4,43 & 2,96 & 6,54 & 2,89 \\
\cline { 2 - 11 } & & 6,04 & 6,55 & 6,69 & 7,16 & 7,14 & 6,86 & 8,60 & 6,73 \\
\hline
\end{tabular}


When the table is analysed, it was discovered that the fields of intelligence did not differentiate distinctly according to the age. The closest field of intelligence for the students in all age groups is existential intelligence and the most distant field of intelligence is verbal-linguistic intelligence. When we considered the fields which are the 2nd closest, it was discovered that it was musical-rhythmic and harmonic intelligence for the students between 18-22 age and intrapersonal intelligence for the students over 28 . When we analysed the 2 nd most distant fields within the scope of the variable of age, it was discovered that it was intrapersonal intelligence for the students between 18-22 ages, musical-rhythmic-harmonic intelligence for the student between 23-17 ages and bodily-kinesthetic intelligence for the students over 28 .

Table 3:- Dispersion of the Fields of Intelligence According to Departments ( $\mathrm{n}=205)$

\begin{tabular}{|l|l|c|c|c|c|c|c|c|c|c|}
\hline \multicolumn{2}{|c}{} & BZ & VZ & KZ & IZ & MZ & MÜZ & DZ & SZ & GZ \\
\hline Physical Education & Average & 8,69 & $\mathbf{6 , 7 3}$ & 7,50 & 7,43 & 8,18 & 7,94 & 7,71 & 9,94 & 7,66 \\
\cline { 2 - 10 } Teaching (n=109) & Standard Deviation & 4,20 & 3,64 & 3,03 & 4,09 & 4,13 & 4,01 & 3,46 & 5,32 & 3,38 \\
\hline Coaching Education & Average & 6,71 & $\mathbf{5 , 8 2}$ & 5,93 & 6,73 & 6,18 & 6,46 & 6,57 & $\underline{7,21}$ & 6,07 \\
\cline { 2 - 10 } (n=56) & Standard Deviation & 4,16 & 3,47 & 3,25 & 4,42 & 3,61 & 3,78 & 3,87 & 4,52 & 3,43 \\
\hline Sports Management & Average & 5,85 & $\mathbf{4 , 4 8}$ & 4,83 & 4,63 & 5,75 & 5,90 & 4,98 & $\underline{6,92}$ & 5,10 \\
(n=40) & Standard Deviation & 4,19 & 3,11 & 2,67 & 3,10 & 4,28 & 4,22 & 2,82 & 5,84 & 2,89 \\
\hline Total (n=205) & Average & 7,60 & $\mathbf{6 , 0 4}$ & 6,55 & 6,69 & 7,16 & 7,14 & 6,86 & $\underline{8,60}$ & 6,73 \\
\cline { 2 - 10 } & Standard Deviation & 4,34 & 3,58 & 3,20 & 4,13 & 4,15 & 4,07 & 3,61 & 5,39 & 3,45 \\
\hline
\end{tabular}

In accordance with the analyses, the closest field of intelligence for the students in the three different departments was determined as existential intelligence. The closest department to the existential intelligence among these departments was determined as sports management. In the third part, verbal-linguistic intelligence was determined as the most distant field of intelligence and it was discovered that the sports management students were the most distant group to this field. In order to find a possible difference, when the fields of intelligence which are the 2nd and 3rd closest were analysed, it was discovered that intrapersonal and interpersonal intelligence was closest to the Physical Education Students. Interpersonal intelligence was the closest for the coaching education students and intrapersonal, interpersonal and naturalistic intelligences were the closest for the Sports Management students.

Table 4:- Dispersion of the Fields of Intelligence According to Years.

\begin{tabular}{|c|c|c|c|c|c|c|c|c|c|c|}
\hline & & $\mathrm{BZ}$ & $\mathrm{VZ}$ & $\mathrm{KZ}$ & İZ & MZ & MÜZ & $\overline{\mathrm{DZ}}$ & SZ & GZ \\
\hline \multirow{2}{*}{$\begin{array}{l}\text { 1st year } \\
\text { (n: 59) }\end{array}$} & Average & 7,75 & 6,66 & 7,02 & 6,93 & 7,25 & 7,32 & 7,41 & 9,14 & 7,20 \\
\hline & Standard Deviation & 4,49 & 3,77 & 3,37 & 3,89 & 4,25 & 4,14 & 3,74 & 5,64 & 3,47 \\
\hline \multirow{2}{*}{$\begin{array}{l}\text { 2nd year } \\
(\mathrm{n}: 71)\end{array}$} & Average & 8,30 & 6,86 & 7,03 & 7,51 & 7,51 & 7,48 & 7,37 & 9,06 & 7,49 \\
\hline & Standard Deviation & 3,85 & 3,68 & 3,00 & 4,21 & 3,64 & 3,55 & 3,50 & 4,32 & 3,42 \\
\hline \multirow{2}{*}{$\begin{array}{l}\text { 3rd year } \\
\text { (n: 42) }\end{array}$} & Average & 7,14 & 5,26 & 5,98 & 6,33 & 7,10 & 7,00 & 6,36 & 8,00 & 5,74 \\
\hline & Standard Deviation & 4,57 & 3,29 & 3,11 & 4,38 & 4,53 & 4,43 & 3,53 & 5,86 & 3,00 \\
\hline \multirow{2}{*}{$\begin{array}{l}\text { 4th year } \\
\text { (n: 33) }\end{array}$} & Average & 6,39 & 4,18 & 5,39 & 4,97 & 6,33 & 6,27 & 5,45 & 7,45 & 5,48 \\
\hline & Standard Deviation & 4,63 & 2,47 & 3,13 & 3,66 & 4,59 & 4,54 & 3,36 & 6,32 & 3,51 \\
\hline \multirow{2}{*}{$\begin{array}{l}\text { Total } \\
\text { (n: 205) }\end{array}$} & Average & 7,60 & 6,04 & 6,55 & 6,69 & 7,16 & 7,14 & 6,86 & 8,60 & 6,73 \\
\hline & Standard Deviation & 4,34 & 3,58 & 3,20 & 4,13 & 4,15 & 4,07 & 3,61 & 5,39 & 3,45 \\
\hline
\end{tabular}

When the analysis results were regarded, it was discovered the the closest field of intelligence was exsitential intelligence for all classes and verbal-linguistic intelligence was the most distant one for them.

Table 5:- Comparison of the Intelligence Scores According to the Variable of Gender (t-test)

\begin{tabular}{|l|l|l|c|c|c|}
\hline Fields of Intelligence & $\begin{array}{l}\text { Female } \\
\mathbf{x} \pm \mathbf{s s}\end{array}$ & $\begin{array}{l}\text { Male } \\
\mathbf{x} \pm \mathbf{s s}\end{array}$ & $\mathbf{t}$ & $\mathbf{p}$ & Result \\
\hline Bodily-Kinesthetic Intelligence & $7,08 \pm 4,14$ & $7,98 \pm 4,46$ & 1,48 & 0,14 & $\mathrm{p}>0,05$ \\
\hline Existential Intelligence & $5,72 \pm 3,61$ & $6,29 \pm 3,56$ & 1,14 & 0,26 & $\mathrm{p}>0,05$ \\
\hline Interpersonal Intelligence & $5,97 \pm 3,12$ & $6,98 \pm 3,2$ & 2,28 & 0,02 & $\mathrm{p}<0,05$ \\
\hline Intrapersonal Intelligence & $6,23 \pm 4,08$ & $7,04 \pm 4,16$ & 1,4 & 0,16 & $\mathrm{p}>0,05$ \\
\hline Logical-Mathematical Intelligence & $6,52 \pm 3,89$ & $7,64 \pm 4,3$ & 1,92 & 0,06 & $\mathrm{p}>0,05$ \\
\hline Musical-Rhythmic-Harmonic Intelligence & $6,56 \pm 3,87$ & $7,58 \pm 4,17$ & 1,79 & 0,07 & $\mathrm{p}>0,05$ \\
\hline Naturalistic Intelligence & $6,23 \pm 3,46$ & $7,34 \pm 3,66$ & 2,21 & 0,03 & $\mathrm{p}<0,05$ \\
\hline Verbal-Linguistic Intelligence & $7,74 \pm 4,93$ & $9,26 \pm 5,64$ & 2,01 & 0,05 & $\mathrm{p}=0,05$ \\
\hline Visual-Spatial Intelligence & $6,25 \pm 3,41$ & $7,09 \pm 3,45$ & 1,72 & 0,09 & $\mathrm{p}>0,05$ \\
\hline
\end{tabular}


According to the t-test analysis results, a statisticaly significant difference was found between the males and females in the fields of interpersonal and naturalistic intelligences from the point of intelligence field scores $(\mathrm{p}<0,05)$. Women's being closer to the fields of intelligence discovered as closeness when compared to men is explained with the analysis of the averages the women are closer than men.

Table 6:- Comparison of the Scores of the Fields of Intelligence According to the Variable of Age (ANOVA)

\begin{tabular}{|l|c|c|c|}
\hline \multicolumn{1}{|c|}{ Fields of Intelligence } & F Value & Level of Significance & Result \\
\hline Bodily-kinesthetic intelligence & 5,87 & 0,00 & $\mathrm{p}<0,05$ \\
\hline Interpersonal intelligence & 16,45 & 0.00 & $\mathrm{p}<0,05$ \\
\hline Logical-mathematical intelligence & 3,47 & 0,03 & $\mathrm{p}<0,05$ \\
\hline Musical-rhythmic-harmonic intelligence & 2,62 & 0,08 & $\mathrm{p}>0,05$ \\
\hline Visual-spatial intelligence & 15,42 & 0.00 & $\mathrm{p}<0,05$ \\
\hline
\end{tabular}

ANOVA test was made to compare the scores of the fields of intelligence according to the variable of age and the bodily-kinesthetic, interpersonal, logical-mathematical, musical-rhythmic-harmonic and visual-spatial intelligences which have homogeneous dispersions were analysed. According to the Anova analysis results, a significant difference was found between the bodily-kinesthetic, interpersonal, logical-mathematical and visual-spatial intelligences and the variable of age from the point of the fields of intelligence $(p<0,05)$. When the Tukey results were regarded, it was found that the significant difference in the scores of the logical-mathematical, bodilykinesthetic, visual-spatial and interpersonal intelligences respectively orginated from the 28 and over age group. The students in this age group took scores closer to these fields when compared to the others.

Table 7:- Comparison of the Scores of the Fields of Intelligence According to the Variable of Department (ANOVA)

\begin{tabular}{|l|c|c|c|}
\hline \multicolumn{1}{|c|}{ Fields of Intelligence } & F Value & Level of Significance & Result \\
\hline Bodily-Kinesthetic Intelligence & 8,42 & 0.00 & $\mathrm{p}<0,05$ \\
\hline Interpersonal Intelligence & 13,01 & 0.00 & $\mathrm{p}<0,05$ \\
\hline Logical-Mathematical Intelligence & 7,64 & 0,03 & $\mathrm{p}<0,05$ \\
\hline Musical-Rhythmic-Harmonic Intelligence & 4,95 & 0,01 & $\mathrm{p}<0,05$ \\
\hline Verbal-linguistic Intelligence & 7,59 & 0.00 & $\mathrm{p}<0,05$ \\
\hline Visual-spatial Intelligence & 10,3 & 0.00 & $\mathrm{p}<0,05$ \\
\hline
\end{tabular}

According to the Anova analysis results, a significant difference was found in all departments according to the variable of department except the Musical-rhythmic-harmonic intelligence ( $<<0,05)$. According to the Tukey analysis made to find from which department did the difference originate from, this difference is on behalf of the Sports Management students among the Physical Education Teaching and Sports Management students in all fields except the Musical-rhythmic-harmonic field of intelligence.

Table 8:- Comparison of the Scores of the Fields of Intelligence According to the Variable of Year (ANOVA)

\begin{tabular}{|l|c|c|c|}
\hline \multicolumn{1}{|c|}{ Fields of Intelligence } & F Value & Level of Significance & Result \\
\hline Bodily-kinesthetic Intelligence & 1,65 & 0,18 & $\mathrm{p}>0,05$ \\
\hline Interpersonal Intelligence & 2,92 & 0,04 & $\mathrm{p}<0,05$ \\
\hline Intrapersonal Intelligence & 3,09 & 0,03 & $\mathrm{p}<0,05$ \\
\hline Logical-mathematical Intelligence & 0,61 & 0,61 & $\mathrm{p}>0,05$ \\
\hline Musical-rhythmic-harmonic Intelligence & 0,72 & 0,54 & $\mathrm{p}>0,05$ \\
\hline Naturalistic Intelligence & 2,94 & 0,03 & $\mathrm{p}<0,05$ \\
\hline Verbal-linguistic Intelligence & 1,03 & 0,38 & $\mathrm{p}>0,05$ \\
\hline Visual-spatial Intelligence & 4,31 & 0,01 & $\mathrm{p}<0,05$ \\
\hline
\end{tabular}

According to the analysis results, a significant difference was found between the variable of years and the interpersonal, intrapersonal, naturalistic and visual-spatial intelligences $(\mathrm{p}<0,05)$. Tukey analysis which was made to find from which part the difference originated from was evaluated and it was discovered that there was not a 
significant difference between the years and the bodily-kinesthetic, interpersonal, logical-mathematical, musicalrhythmic-harmonic, naturalistic and verbal-linguistic intelligences. It was found that there was a significant difference between the 2nd and 4th year students within the intrapersonal intelligence scores and the 4th year students were closer to the intrapersonal intelligence. When the visual-spatial intelligence scores were analysed, it was discovered that there was a significant difference between the 2 nd year, 3rd year and 4th year students and the 4 th year students were closer to visual-spatial intelligence when compared to the others.

\section{Discussion, Result and Suggestions:-}

Within the compass of the results obtained, it was discovered that the students in all 3 departments had the characteristics of Existential Intelligence. In the studies made in the literature, Kahraman and Bavli (2014) found the intelligence modalities of 100 SPES students as 'Intrapersonal, Interpersonal and Bodily-Kinesthetic' and he found their distant intelligence modalities as "Musical-rhythmic-harmonic, Verbal-linguistic, Naturalistic and Visualspatial" respectively. Again, Çinkılıç and Soyer (2013) determined the close field of intelligence as the "Bodilykinesthetic" intelligence and he dtermined the distant field of intelligence as "Visual-spatial" intelligence. Güllü and Tekin (2009) made the alignment of the sports high school students as "Bodily-kinesthetic, social-interpersonal, intrapersonal, verbal-linguistic, naturalistic, logical-mathematical, visual-spatial and musical-rhythmic-harmonic" and according to these results. He interpreted that the most developed intelligence modality of the sports high school students was bodily-kinesthetic intelligence and their second most developed intelligence modality was socialinterpersonal intelligence and their third most developed intelligence modality was intrapersonal intelligence. Kul et al (2014), reported that the closest intelligence field for the SPES students were 'Interpersonal' and "Bodilykinesthetic" intelligence. The most distant intelligence fields for them were "Musical-rhythmic-harmonic" and "visual-spatial" intelligences in the multiple intelligences study he conducted with the students who passed the SPES exam.

Kiremitçi and Canpolat (2014) determined the closest intelligence fields for the SPES students as "Bodilykinesthetic, interpersonal and intrapersonal" and the most distant intelligence fields for them as "Naturalistic, Verbal-linguistic and Musical-rhythmic-harmonic" intelligences. However, Tuncer (2011) wrote that "The SPES students were expected to have "Bodily-kinesthetic" intelligence but the Naturalistic intelligence of these students were more developed" in his research. As for the results of the $t$ test in which the intelligence fields are compared according to gender, it was discovered that the females were closer to the interpersonal, naturalistic and verballinguistic intelligences which have a homogeneous dispersion when compared to males. When we regarded the fields of intelligence specificly, we may think that these fields of intelligence were closer when compared to the men. Because the women's communication skills are more intrinsic than men's, their interaction with their environment can be more intensive and their faculty of expressing themselves are higher than men's.

Although the results we have discovered are significant, the results of the studies about the intelligence fields of the SPES students and the results of this study are similar at some points but it has been determined that they are different when compared to many studies.

The most distant intelligence field of the Çukurova University SPES students is "Verbal-linguistic intelligence". The closest field was discovered as the "Existential Intelligence." In the tests made in accordance with the variables in the analyses, it was discovered that the females were closer to the existential intelligence when compared to males. It was also discovered that males were more distant to the verbal-linguistic intelligence as the distant field of intelligence when compared to females. When the 2 nd level closeness was regarded, it was discovered that the males were close to the interpersonal intelligence and the females were close to interpersonal and intrapersonal intelligences. Although it became 2nd in the research we made, among the similar studies which discovered that females were closer to the intrapersonal intelligence, the intelligence scores of the males and females who joined the studies of Karakaş et al (2014) were compared. Difference on behalf of females were found in all fields except interpersonal intelligence. The study made by Güllü and Tekin (2009) with the sports high school and general high school students was analysed. It is observed that there are significant differences on behalf of girls among the "Verbal-linguistic, Visual-spatial, Musical-rhythmic-harmonic, Social-interpersonal and Intrapersonal" intelligences according to the genders of the students.

In contrast with our findings, in the studies by Çinkılıç and Soyer (2013), it was found that a difference on behalf of males was discovered only in the field of "intrapersonal intelligence" among male and female SPES students. No difference occurred in the other fields of intelligence. As a result of the study conducted by Yazicı and Acar (2010) 
in another field on multiple intelligences, differences were found on behalf of women in the fields of "Musicalrhythmic-harmonic Intelligence" and on behalf of men in the field of "Bodily-kinesthetic" intelligence. Moreover, İzci et al report that there are no significant difference between the intelligence modalities in their studies on multiple intelligences with students in different fields. When the literature is regarded, it is observed that different results were obtained according to the variable of gender in the studies comparing the fields of intelligence.

When the fields of intelligence were analysed according to age, it was discovered that the closest field of intelligence was existential intelligence and the most distant field of intelligence was verbal-linguistic intelligence, like the variable of gender. The analysis was scrutinised thinking that the different fields of intelligence we discovered as the 2 nd according to the variable of gender could also be in the variable of age. Musical-rhythmicharmonic intelligence was found in the 18-22 age range, visual-spatial intelligence was found in the 23-27 age range and intrapersonal inteligence was found in 28 and over age group as the 2 nd closest intelligence modality. If we interpret the averages, since there is a more suitable physical structure in the students in the 18-22 age range when compared to the other students in terms of rhythm and activity, it can be said that they are closer to musicalrhythmic-harmonic intelligence. Especially in this age range, individuals have to show physical development performance because of the SPES exam preparation (speed test, coordination track and other ability measurements). This situation explains that the students' feeling of rhythm is advanced. In the 23-27 age range, since ability to recognize with seeing and describing are reinforced more than activity, the students try to educate themselves in the field of visual learning also having academical education besides physical compatibility. So, it can be thought that it is possible for them to be closer to visual-spatial intelligence. In the students in the 28 and over age group, their getting close to intrapersonal intelligence shapes with the interiorisation, comparison and interpretation of the knowlede and experience as directly porportional to the education they have. Intrapersonal intelligence, which is defined as the individual's ability to define himself, can be interpreted as explaining why it is closer than the other fields of intelligence in this age range.

It was determined that the students over 28 among the age groups were closer to the Logical-mathematical, Bodilykinesthetic, Visual-spatial and Interpersonal fields of intelligence in the findings obtained with the ANOVA test made in order to compare the age's being close to the fields of intelligence. The interpretation of this alignment from a SPES graduate's point of view is, the students determine what they can do as a job and their position in the future in this age group ( 28 and over). In accordance with these wishes, they widen their communication network involving in a social interaction for firstly determining a target logically, regarding themselves as physicallly ready, being able to interpret what they see with their experience and for preparing themselves for their future. This point of view may be thought to interpret the analysis results directly proportionally.

When the fields of intelligence are analysed according to the variable of department, it was determined that all of the students in 3 different departments were close to existential intelligence. The inclination of the students who prefer SPES for sports and their targeting sports as a career can explain their closeness to "Existential Intelligence." When the averages were analysed, the closest department to the "Existential Intelligence" was found as Sports Management and the most distant department was found as Physical Education Teaching. Because the students who choose to be teachers determine teaching as the only target when they graduate. However, since the students who choose Sports Management can be in many platforms of sports after they graduate, there is a continuous change and development in their targets. Because of this reason, it can be thought that they are closer to "Existential Intelligence". When the second and third closest fields of intelligence were analysed, it was discovered that the students of Physical Education Teaching were close to Intrapersonal and Interpersonal Intelligence. Coaching Education students were close to Interpersonal and Visual-spatial Intelligence and Sports Management students were closer to Intrapersonal, Interpersonal and Naturalistic Intelligences. In accordance with these results, it was thought that the choices and education of the students in accordance with the own dynamics of the departments were for the fields of intelligence. The closeness to the "Interpersonal Intelligence" in all three departmentscan be interpreted with the aim of developing on the basis of people in all of the departments within the scope of SPES. Some fields of intelligence did not have homogeneous dispersions during the ANOVA test applied in the stage of comparing the intelligence fields with the department variables. So, the bodily-kinesthetic, interpersonal, logical-mathematical, musical and verbal-linguistic intelligences were analysed with Anova test as the subdimensions which had homogeneous dispersions. A significant difference was found between these fields and the department variables and it was discovered that the Sports Management students were closer to the 6 intelligence modalities analysed when compared to the other students. In Sports Management, sports existed in all areas in which sports is the subject; management, superintendence, organization and supervision foremost. If we consider that, we can interpret it as the 
reason why the Sports Management students were close to the bodily-kinethetic, interpersonal, logicalmathematical, musical, verbal-liguistic and visual-spatial intelligences.

If we evaluate things specific to the study, the reason of the closeness of the SPES students to existential intelligence can be thought that the individuals' being inclined to question, create difference in the future, be able to stay and advance within the system. It can explain why they are close to this field. The students in the department of Sports Management which can be considered as new when compared to other SPES departments are close to this field. We think that it explains a structure which the students adopt and undertake as a duty from the point of completing the deficiencies in this area. Since I am one of the graduates who completed her education in the Sports Management department of the same university and one of the first graduates of the university in this department, I think that I can observe this situation in a more meaningful way. Hence, we were taught that we should be in the management areas of sport in the future and because of this reason we had to develop ourselves continuously from the first term we started education. During our education, the necessity of developing work not only as a sports department but also in all fields of sport was interiorised. For example, when a programme like ERASMUS was unkonwn in our region as SPES, we searched this topic as the department students and we had the opportunity to experience the ERASMUS programme as both students and academics. Although the SPES departments became famous in Turkey adopted this kind of programmes, Çukurova University SPES department can be considered as first in this topic. Apart from that, we had experiences because we were motived for research from the 1st year and we organized the symposiums, seminaries and workshops we joined in our school. Many events we started as the first graduates were made active and continuous in the later years. We think that this breakthrough represents development in the name of our department. Since I am one of the graduates who completed her education in the Sports Management department of the same university and one of the first of the university in this department, I think that I can observe this situation in a more meaningful way. Hence, we were taught that we should be in the management areas of sport in the future and because of this reason we had to develop ourselves continuously from the first term we started education. During our education, the necessity of developing work not only as a sports department but also in all fields of sport was interiorised. For example, when a programme like ERASMUS was unkonwn in our region as SPES, we searched this topic as the department students and we had the opportunity to experience the ERASMUS programme as both students and academics. Although the SPES departments became famous in Turkey adopted this kind of programmes, Çukurova University SPES department can be considered as first in this topic. Apart from that, we had experiences because we were motived for research from the 1st year, and we organized the symposiums, seminaries and workshopswe joined in our school. Many events we started as the first graduates were made active and continuous in the later years. We think that this breakthrough represents development in the name of our department.

When the results were analysed according to the variable of class, it was discovered that the 4th year students were more distant to the "'Verbal-linguistic Intelligence"' which was the closest and the most distant to the "'Existential Intelligence" than the 1st year students. When the literature was studied, it was observed that the variables of age and year were not evaluated in a significant way in the dipsersion of the fields of intelligence. Because of this reason, no studies to make a comparison could be found.

Differentiation of the fields of intelligence in accordance with these variables have the quality to remark that the students can change within the process. Since there are few studies to be compared to the study made in the literature, this study can be said to be heuristic. Because of this reason, multiple intelligence modalities are thought to provide a basis for an original study beyond discovery in accordance with the findings to be obtained, including the SPES departments of different universities in a wide range. Thus, we think that it will contribute to the SPES students' creating awareness in their fields and it will also contribute to the individuals who take part in sports in our country for being in sports as accomplished individuals.

\section{Kaynakça:-}

1. Altun, I. (2003). The Perceived Problem Solving Ability And Values Of Student Nurses And Midwives. Nurse Education Today, 23: 575-584.

2. Saracaloğlu, A.S., Yenice N. Ve Karasakaloğlu, N. (2009). Öğretmen Adaylarının İletişim Ve Problem Çözme Becerileri İle Okuma İlgi Ve Alışkanlıkları Arasındaki İlişki. Yuzuncu Yıl Universitesi Eğitim Fakultesi Dergisi, 6(2), 187-206.

3. Gök, B. Ve Erdoğan, T. (2011). Sınıf Öğretmeni Adaylarının Yaratıcı Düşünme Düzeyleri Ve Eleştirel Düşünme Eğilimlerinin İncelenmesi. Ankara Universitesi Eğitim Bilimleri Fakultesi Dergisi, 44(2), 29-51. 
4. Chongde, L., Tsingan, L. (2003). Multiple Intelligence And The Structure Of Thinking. Theory Psychology, 13(6):829-845.

5. Azar, A., Presley, A. I. Ve Balkaya, Ö. (2006). Çoklu Zekâ Kuramı Temelli Öğretimin Öğrencilerin Başarı, Tutum, Hatırlama Ve Bilişsel Süreç Becerilerine Etkileri. Hacettepe Universitesi Eğitim Fakultesi Dergisi, 30, 67-75.

6. Saban, A. (2005). Çoklu Zekâ Teorisi Ve Eğitim. 5. Baskı, Nobel Yayın Dağıtım, Ankara.

7. Gardner, H. (1993). Multiple İntelligences: The Theory İn Practice. New York: A Division Of Harper Collins Publishers.

8. Mcclellan, J. A., Conti, G. J. (2008). Identifying The Multiple İntelligences Of Your Students. Journal Of Adult Education, 37 (1), 13-32.

9. Babacan, T., Dilci, T. (2012). Çoklu Zekâ Ölçeği’nin Türkçeye Uyarlama Çalışmaları. E- Journal Of New World Sciences Academy, 7(3):969-982.

10. Kahraman, D.İ., Bavli, Ö. (2014). Investigation The Multiple İntelligence Areas Of University Students Who Study İn Different Departments. International Journal Of New Trends İn Arts, Sports \& Science Education (IJTASE), 3(3):65-71.

11. Çinkılıç, İ., Soyer, F. (2013). Beden Eğitimi Öğretmen Adaylarının Çoklu Zekâ Alanları İle Problem Çözme Becerileri Arasındaki İlişkinin İncelenmesi. Spor Yönetimi Ve Bilgi Teknolojileri Dergisi, 8(1):4-16.

12. Güllü, M., Tekin, M. (2009). Spor Lisesi Öğrencileri İle Genel Lise Öğrencilerinin Çoklu Zekâ Alanlarının Karşılaştırılması. Niğde Üniversitesi Beden Eğitimi Ve Spor Bilimleri Dergisi, 3(3):247-258.

13. Kul, M., Bozkuş, T., Erol, Z., Elçi, G. (2014). Beden Eğitimi Ve Spor Yüksekokulu Sinavlarında Kayıt Yaptırmaya Hak Kazanan Adaylar İle Hak Kazanamayan Adayların Çoklu Zekâ Alanların Karşılaştırılmasıüzerine Bir Araştırma. International Journal Of Science Culture And Sport, Special Issue $1: 891-897$.

14. Kiremitçi, O., Canpolat, M.A. (2014). Beden Eğitimi Ve Spor Yüksekokulu Öğrencilerinin Çoklu Zekâ Alanlarının Üstbilişsel Farkındalık Ve Problem Çözme Becerilerini Belirlemedeki Rolü. Spor Bilimleri Dergisi Hacettepe Journal Of Sport Sciences, 25(3):118-126.

15. Tuncer, M. (2011). ÖSYM Tarafindan Yükseköğretim Programlarına Yapılan Yerleştirmelerin Çoklu Zekâ Kuramı Perspektifinden Değerlendirilmesi. Firat Üniversitesi Sosyal Bilimler Dergisi, 21(1):89-111.

16. Karakaş, F., Ermiş, E., Erilli, N.A. (2014). Polis Meslek Yüksekokulu Öğrenci Adaylarının Fiziki Yeterlilik Parkur Süresi İle Çoklu Zekâları Ve Cinsiyet Arasındaki İlişkinin İncelenmesi. Spor Ve Performans Araştırmaları Dergisi, 5(1):18-26.

17. Yazıcı, E.Ö., Acar, E.(2010).Yapım Yöneticilerinin Çoklu Zekâ Profillerinin Belirlenmesi. 1.Proje Ve Yapım Yönetimi Kongresi 29 Eylül- 1Ekim 2010 ODTÜ Kültür Ve Kongre Merkezi,:1064-1075

18. İzci, E., Kara, A., Dalaman, F. (2007). Dershane Öğrencilerinin Çoklu Zekâ Kuramı Açısından İncelenmesi. Pamukkale Üniversitesi Eğitim Fakültesi Dergisi, 21(1):1- 14. 